\title{
Efficacy Advanced Chemical Oxidation Process (AOP) for Sustainable Pretreatment of Mixed Dairy and Poultry Wastewaters in Nablus, Palestine
}

\section{Saja Younes, Rashed Al-Sa`ed* ID}

Institute of Environmental and Water Studies (IEWS), Birzeit University (BZU), Birzeit, Palestine.

*Corresponding author: E-mail address: rsaed@birzeit.edu

\begin{abstract}
This study investigated the efficacy of advanced oxidation process (AOP) for the reduction of pollution loads in mixed agro-food industrial wastewaters (dairy and slaughterhouse) in Nablus city, Palestine. Bench scale Jar tests using an advanced oxidation process (AOP) were performed as a pretreatment stage. Initial results on direct applications of Fenton's process on mixed agro-food wastewater (COD: 15400-18200 mg/l) were unsatisfactory. Hence, the performance of Fenton process was applied on three mixed wastewater samples with different pre-treatment trials: $(\mathrm{A})$ coagulant $\left(\mathrm{FeCl}_{3} \cdot 6 \mathrm{H}_{2} \mathrm{O}\right)$ addition, (B) settling (2h) and use of flocculent (lime $\mathrm{Ca}(\mathrm{OH})_{2}$ ) in sample (C). Preceded with lime, Fenton`s process (Sample C) was most effective in the removal of organic carbon and nitrogen (89\% COD; 80\% TKN). The removal efficiency in inorganic loads (91\% TSS; 62\% TS) were achieved under $\mathrm{H}_{2} \mathrm{O}_{2} / \mathrm{COD}$ (w/w ratio 2:1), $\mathrm{H}_{2} \mathrm{O}_{2} / \mathrm{Fe}^{+2}$ (w/w ratio 10:1) and acidic conditions $(\mathrm{pH}=3)$. The adoption of AOP technology by agro-food industries could ensure compliance with municipal by-laws and acquire connection permits to sewerage networks.
\end{abstract}

Keywords: Advanced oxidation processes; Fenton reaction; sustainable agro-industrial sector; sewer connection permit.

\section{Introduction}

Agro-food industries, established mainly in rural communities, produce industrial effluents containing high organic pollution loads, which pose negative impacts on environment, sewer networks and municipal wastewater treatment plants (WWTPs). 
Wastewater effluents from dairies and poultry slaughterhouses, are organic-rich wastewater streams that require pretreatment prior connection to public sewer networks or illicitly discharged into receiving water bodies. Agro-food industrial wastewater have high biological oxygen demand (BOD) due to whey and blood contents. Wastewater originating from the various manufacturing processes have high contents of proteins, fats, and salts [1-3]. In addition, the remnants of the slaughterhouse due to the blood and the proudest wastewater from slaughtered animal [4]. Finding adequate treatment technologies for the pretreatment pertinent to pollution reduction and resources recovery is crucial.

In Palestine current water and environmental laws and water regulations, place national limits on industrial discharges and treated effluent from domestic and municipals dischargers, where Cabinet made Resolution Number (16) for the year 2013, "Bylaw on the House and Facilities' Connection System to the Public Sewage Network". The resolution for item (16) focus on the specification of industrial wastewater, where the COD limit is $2000 \mathrm{mg} / \mathrm{l}$ in order to allow to the industry to connect to the public sewage system [5]. These limits primarily aim at the reduction of organic and inorganic pollution loads, which promote eutrophication and impair public sewers [6], treatment facilities, environment, and public health. Consequently, municipal by-laws and effluent discharge standards dictate the level of wastewater treatment required and call for pretreatment of industrial effluents before connection to public sewer networks [5].

Limited access to water resources in Palestine, lack of financial resources and increasingly stringent local and regional regulations on municipal and industrial discharges, industries are under enormous pressures to reduce pollution loads by establishing advanced treatment and recycling of treated water in destined industrial production processes. All urban WWTPs in Palestine are designed to treat municipal wastewater but cannot adequately co-treat agrofood industrial effluents, which cause overloading in treatment processes and pollution of receiving natural watercourses. This study was conducted within the framework of INWA project, a Palestinian Dutch Cooperation (PADUCO) Program on Water. The study aimed at investigating the advanced oxidation process (AOP), a classical Fenton reaction, in the reduction of organic loads from mixed agro-food industrial wastewaters to enable safe connection to public sewer networks. 


\section{Materials and Methods}

Samples of agro-food industrial wastewater have been collected from the dairy factory, and municipal slaughterhouse. The mixed of the previous samples have been tested to determine their physical and chemical properties. All samples prepared according to APHA (2005) [7]. The dairy samples contain sodium hydroxide $(\mathrm{NaOH})$ and phosphoric acid $\left(\mathrm{H}_{3} \mathrm{PO}_{4}\right)$ with concentrations (2.8-3\%) which come from flushing, rinsing and disinfecting of the process tanks and piping, in addition to the whey which is separated in the cheese making process, while the samples from slaughterhouse contained diluted blood, and wastewater produced from washing the slaughtered animals (manure, and undigested feed).

Table 1. General characteristics of the mixed agro-food wastewaters.

\begin{tabular}{|l|l|l|}
\hline Parameters & Value and results for the samples & Limits CR 16/13 \\
\hline $\mathrm{pH}$ & $6.96-7.23$ & $5-9.5$ \\
\hline $\mathrm{COD}(\mathrm{mg} / \mathrm{l})$ & $15400-18200$ & 2000 \\
\hline Total solids $(\mathrm{mg} / \mathrm{l})$ & $2400-3705$ & - \\
\hline Total suspended solids $(\mathrm{mg} / \mathrm{l})$ & $188-220$ & 600 \\
\hline BOD $_{5}(\mathrm{mg} / \mathrm{l})$ & $7008-8198$ & - \\
\hline TKN $(\mathrm{mg} / \mathrm{l})$ & $411-570$ & - \\
\hline
\end{tabular}

The results shown above revealed high concentrations in COD loads in the mixed agro-food industrial wastewater from dairy (whey) and blood from the slaughterhouse in Nablus city.

\section{Experimental Procedure}

\subsection{Analytical Methods}

Physical parameters for raw and treated mixed agro-food wastewaters analyzed. The $\mathrm{pH}$ was measured using Metrohm-691, while the TSS and TS parameters according to the APHA Standard Methods [7]. Similarly, chemical parameters including Biological Oxygen Demand (BOD 5 ) 5210 B, Chemical Oxygen Demand (COD) - section 5220 D, total Kjeldahl nitrogen Closed Reflux, Colorimetric Method-, and Ammonia $\left(\mathrm{NH}_{4}-\mathrm{N}\right)$ Nesslerization. 


\subsection{Experimental Procedure}

Classical Fenton's process has been applied with directly and with partially treatment.

Tests applied directly on the mixed of agro-food. Also applied partially for three samples:

1. Sample A: Coagulated by ferric chloride $\mathrm{FeCl}_{3} \cdot 6 \mathrm{H}_{2} \mathrm{O}$.

2. Sample B: Sedimentary sample without coagulant (untreated wastewater).

3. Sample C: Flocculation with Lime $\mathrm{Ca}(\mathrm{OH})_{2}$.

After partially treatment the supernatant, treatment by Fenton reagent applying two methods: without $\mathrm{pH}$ adjustment, and a second one with $\mathrm{pH}$ adjustment to get the desired results.

\subsubsection{Directly Treatment By Fenton Reagent}

The classical Fenton's process was applied for mixed agro-food industrial wastewater samples directly; with initial COD between was $15400-18200 \mathrm{mg} / \mathrm{l}$.

Fenton Reagent experiment:

1) $0.1 \mathrm{~L}$ of supernatant from all samples were prepared to start reaction, with $\mathrm{pH}$ adjustment to a value of three (3) by adding $\mathrm{HCl}$ solution.

2) Catalyst of Ferrous sulfate heptahydrate $\left(\mathrm{FeSO}_{4} \cdot 7 \mathrm{H}_{2} \mathrm{O} ; 5.2 \mathrm{mM} \mathrm{Fe}{ }^{2+}\right)$ added to the sample before adding hydrogen peroxide. The molar ratio of $\mathrm{H}_{2} \mathrm{O}_{2} / \mathrm{Fe}^{2+}$ w/w kept invariable at 10:1 and $\mathrm{H}_{2} \mathrm{O}_{2} / \mathrm{COD}(\mathrm{w} / \mathrm{w})$ kept constant at 2:1.

3) Three equal parts/or at once were added in 3 steps of $\mathrm{H}_{2} \mathrm{O}_{2}$ with wt. $30 \%(9.7 \mathrm{M}$ ) (density $1.11 \mathrm{~g} / \mathrm{cm}^{3}$ ).

4) Terminate oxidation by the adjustment of samples' $\mathrm{pH}$ to 5-9 by adding lime $\mathrm{Ca}(\mathrm{OH})_{2}$. Then, sample was kept for a period of $1 \mathrm{~h}$ to allow settling of solids and analyses of the supernatant followed.

\subsubsection{Experimental Procedure of Partially Treatment samples}

Sample (A) coagulation with ferric chloride $\mathrm{FeCl}_{3} \cdot 6 \mathrm{H}_{2} \mathrm{O}$ : the sample of mixed raw dairy and slaughterhouse wastewater has been adjusted at room temperature $\left(20 \pm 1{ }^{\circ} \mathrm{C}\right)$. Then in the jar 
test $1.0 \mathrm{~L}$ volume of the sample coagulated by using ferric chloride $\left(\mathrm{FeCl}_{3} \cdot 6 \mathrm{H}_{2} \mathrm{O}\right)$ aqueous solution with dosage $1 \mathrm{~g} / \mathrm{L}$, the aqueous coagulant added in rapid mixing at $300 \mathrm{rpm}$ for 3 min, then $30 \mathrm{~min}$ in slow mixing at $40 \mathrm{rpm}$. Followed by two hours of settling [8-9].

Sample (B) with sedimentation without coagulant: A one (1) liter of the raw wastewater (at room temperature) with initial $\mathrm{pH}$ and allowed settling for 2-4 h.

Sample (C) flocculation with Lime $\mathrm{Ca}(\mathrm{OH})_{2}$ : One litter of initial wastewater has been mixed with raw lime $\mathrm{Ca}(\mathrm{OH}) 2$ by adding $1 \mathrm{~g} / \mathrm{l}$ of and mixing it rapidly for creating flocculation [8], [10-11]. After partially treatment, that supernatant of samples had been gotten to complete treatment by Fenton's process as mentioned before once without $\mathrm{pH}$ adjustment and other with $\mathrm{pH}$ adjustment $=3$ and neutralization as following figures.
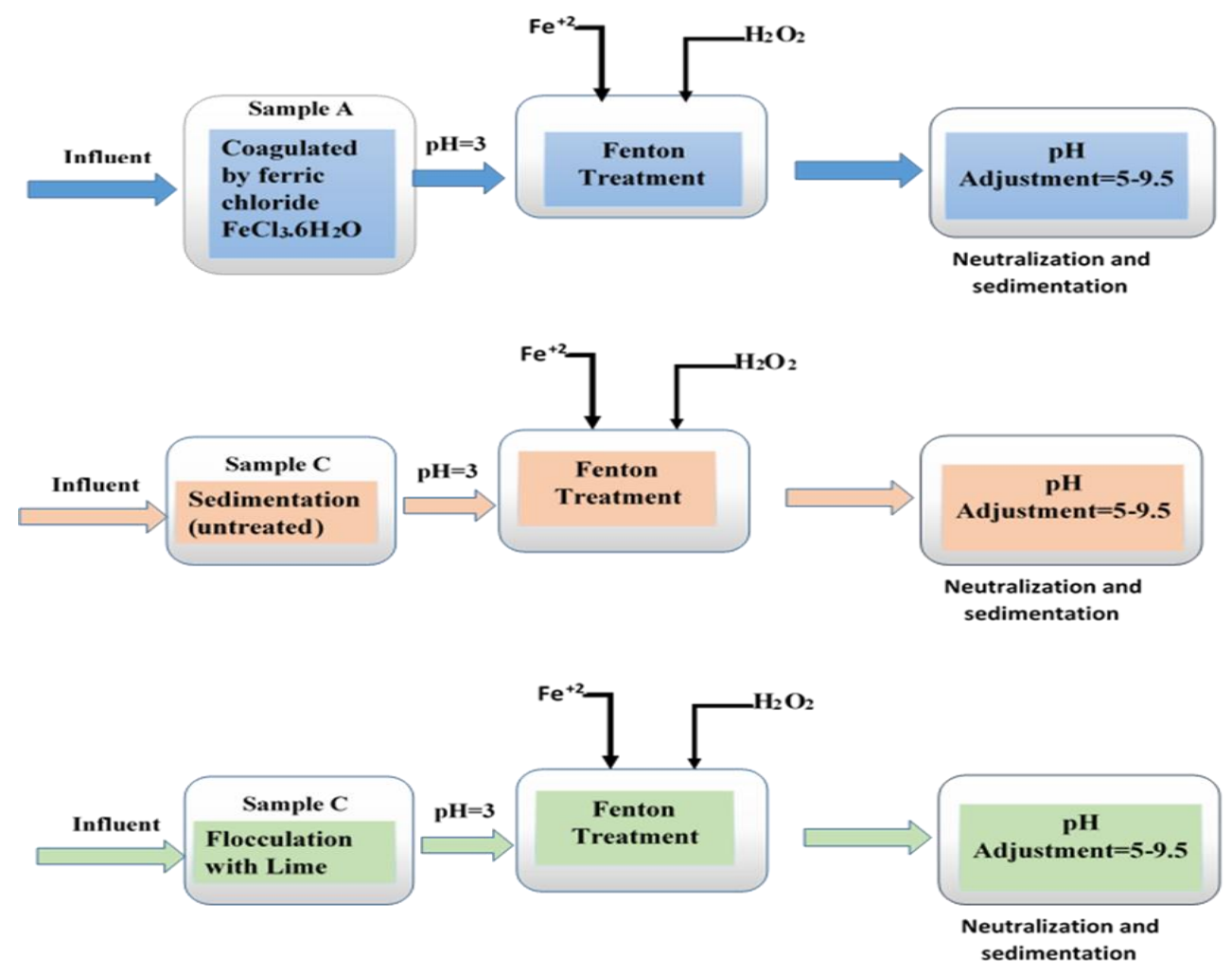

Figure 1. Steps of Fenton reaction experiment with $\mathrm{pH}$ adjustment for three recommended samples. 


\section{Results and Discussion}

\subsection{Direct Treatment by Fenton Reagent}

Mixed samples of agro-food wastewater (poultry slaughterhouse and dairy) were treated directly by Fenton reagent. The results did not achieve the requirements ( $2000 \mathrm{mg} \mathrm{COD} / \mathrm{l})$ of Nablus connection by-law (CR 16/13) due low COD removal rates (45\%) using $\mathrm{H}_{2} \mathrm{O}_{2} / \mathrm{COD}$ and $\mathrm{H}_{2} \mathrm{O}_{2} / \mathrm{Fe}^{+2}$ (w/w) at ratios of 2:1 and 10:1, respectively.

\subsection{Pre-Treatment Results}

\subsubsection{Three Treatment Trials Preceding Fenton Reaction}

The first pre-treatment sample (A) is coagulation with $\mathrm{FeCl}_{3} \cdot 6 \mathrm{H}_{2} \mathrm{O}$. The treatment has been carried out to remove suspended compounds of wastewater through the formation of a solid precipitate (sludge) which will be treated [12]. The treatment carried out with dosage $1 \mathrm{~g} / \mathrm{L}$ of $\mathrm{FeCl}_{3} \cdot 6 \mathrm{H}_{2} \mathrm{O}$ of wastewater. The removal rates for COD are (62\%). This coagulant is also possible for TSS and TS removal $(74 \%, 28 \%)$ respectively. Sedimentation, the second pretreatment (B) sample, was to reduce organic loads and enhance the Fenton process [13]. The result of pre-treatment in removal rates for COD (26\%), this result is feasible to improve wastewater parameters but it's not effective as coagulation with $\mathrm{FeCl}_{3} .6 \mathrm{H}_{2} \mathrm{O}$ and flocculation with lime $\mathrm{Ca}(\mathrm{OH})_{2}$ pre-treatments. The third pre-treatment sample $(\mathrm{C})$ is flocculation with lime $\mathrm{Ca}(\mathrm{OH})_{2}$ [10], [11]. The results revealed higher removal percentages for $\mathrm{COD}(68 \%)$, TSS (58\%), and in TS (19\%). Coupled with Fenton process, the pretreatment (C) trial was selected for the treatment of mixed agro-food wastewater.

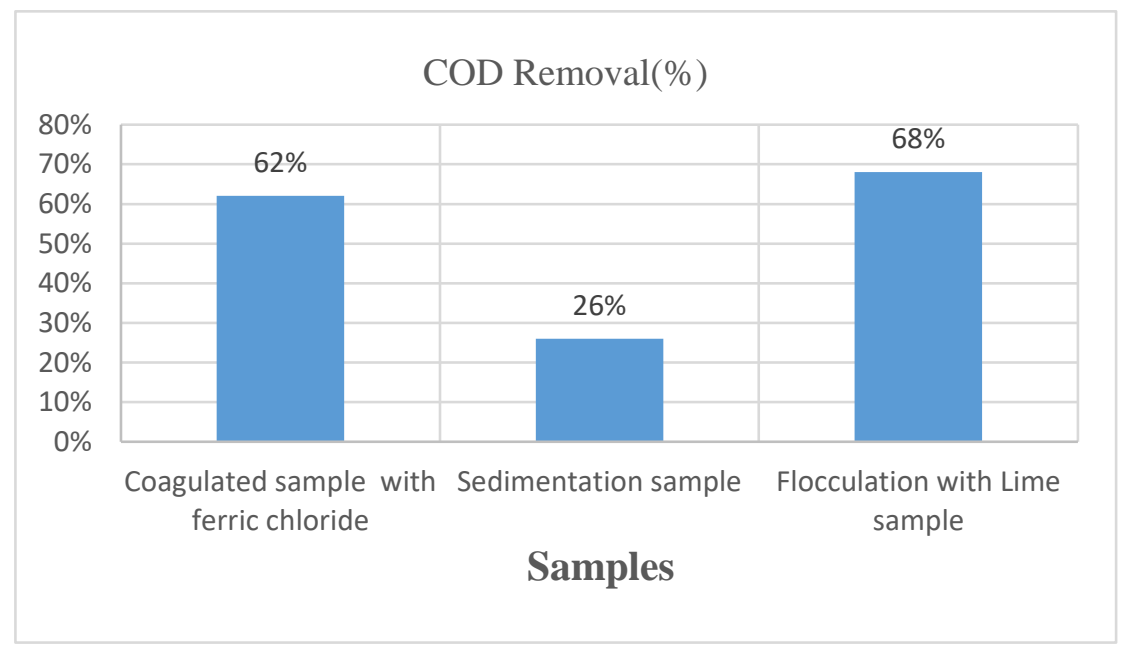

Figure 2. COD removal (\%) for samples after partially treatment. 
According to results of COD removal, Sample A and C had been recommended for further tests.

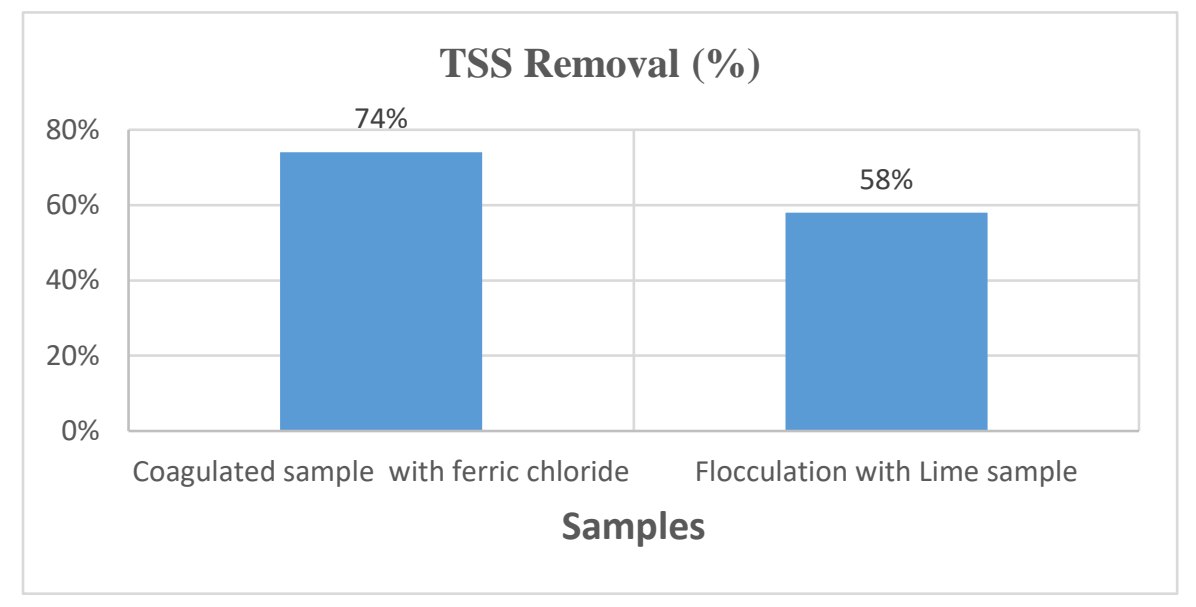

Figure 3: TSS removal (\%) for samples after partially treatment.

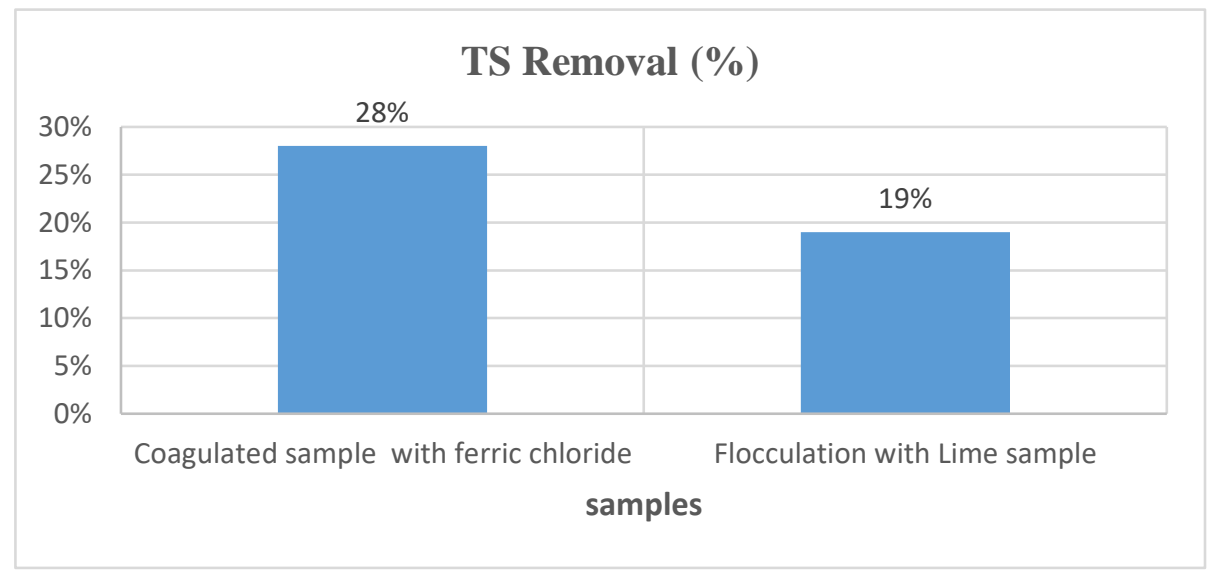

Figure 4. TS removal (\%) for samples after partially treatment.

\subsubsection{Results of Fenton Treatment after Partially Treatment}

\subsubsection{Treatment by Fenton Reagent without pH Adjustment}

At the first time, the $\mathrm{pH}$ was kept unadjusted and start the Fenton reaction for samples:

1. Sample A: Coagulated by ferric chloride $\mathrm{FeCl}_{3} \cdot 6 \mathrm{H}_{2} \mathrm{O}$.

2. Sample B: Sedimentary sample without coagulant (untreated wastewater.

3. Sample C: Flocculation with Lime $\mathrm{Ca}(\mathrm{OH})_{2}$. 
Best result were for sample with flocculation, with a COD removal of 54\% at $\mathrm{pH}$ of 11 and $\mathrm{H}_{2} \mathrm{O}_{2} / \mathrm{COD}(\mathrm{w} / \mathrm{w})$ ratio of 2:1 and a ratio for $\mathrm{H}_{2} \mathrm{O}_{2} / \mathrm{Fe}^{2+}$ of 10:1. COD removal for samples coagulated (ferric chloride) and samples with sedimentation were almost equal (28\% and $26 \%$ respectively) using same reaction conditions for flocculated samples, but at different $\mathrm{pH}$ values ( 8 and 10.5, respectively). Figure 5 depicts the performance of Fenton reaction in COD removal for the three treatment trials.

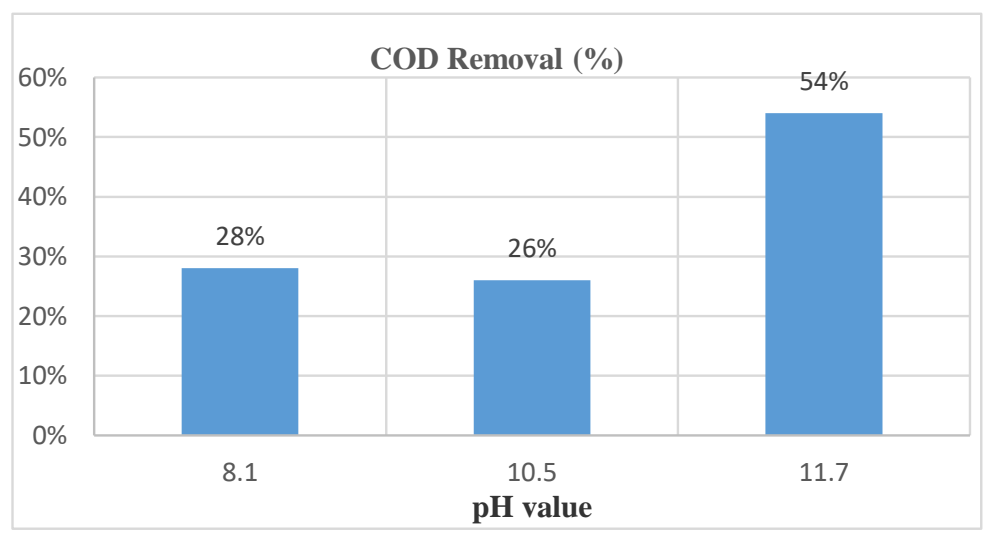

Figure 5. COD removal (\%) for three samples at initial $\mathrm{pH}$ without adjustment.

By leaving the samples without $\mathrm{pH}$ adjusting, the COD removal efficiency is not satisfactory in order to achieve CR 16/13.

\subsubsection{Treatment with $\mathrm{pH}$ Adjustment and Neutralization}

An acidic solution (HCL) has been used to modify the $\mathrm{pH}$ value from basic to acid media in order to make adequate conditions to start reaction. It is found that the degradation efficiency increased rapidly, organic removal was significantly higher in acidic conditions at $\mathrm{pH} 3$ than under alkaline conditions. $\mathrm{pH}$ optimum for Fenton reaction is around 3 based on literature data to avoid precipitation of iron oxide-hydroxide which enhance the reaction [14]. This is crucial to produce hydroxyl radicals, responsible for the breakdown of organic matter and for oxidation reaction [13]. The ratio of $\mathrm{H}_{2} \mathrm{O}_{2} / \mathrm{COD}$ (w/w) was kept 2:1 and $\mathrm{H}_{2} \mathrm{O}_{2} / \mathrm{Fe}^{2+}$ 10:1.

The results of the experiments showed that the best sample in removal of organic load is the flocculation with lime $\mathrm{Ca}(\mathrm{OH})_{2}$. It has been found that the removal rate for COD reached 70 $\%$ and for TSS and TS removal reached 65\%, 47\% respectively, and has been found that TKN reached $80 \%$ with the ratio of $\mathrm{H}_{2} \mathrm{O}_{2} / \mathrm{COD}$ (w/w) $2: 1$ and $\mathrm{H}_{2} \mathrm{O}_{2} / \mathrm{Fe}^{2+} 10: 1$, and at the room temperature and within 1 hour. Samples coagulated with ferric chloride achieved COD 
removal of coagulated by is equal 52\% and for TSS and TS removal reached $68 \% 48 \%$ (Figure 6 and 7). Moreover, TKN reached 69\% removal at the same ratios (Figure 8 and 9).

For the sedimentation sample, the removal rate for COD reached 33\%. The value of COD removal is low, and not accepted so this sample has been excluded for other results. After treatment, all samples have been neutralized at $\mathrm{pH}=7.3$.The performance of Fenton reaction in COD removal shown in Figure 6, for treating three samples. By adjusting the $\mathrm{pH}$, value for the three samples, the COD removal efficiency satisfactory for the sample which pretreating by lime $\mathrm{Ca}(\mathrm{OH})_{2}$, in order to achieve CR 16/13.

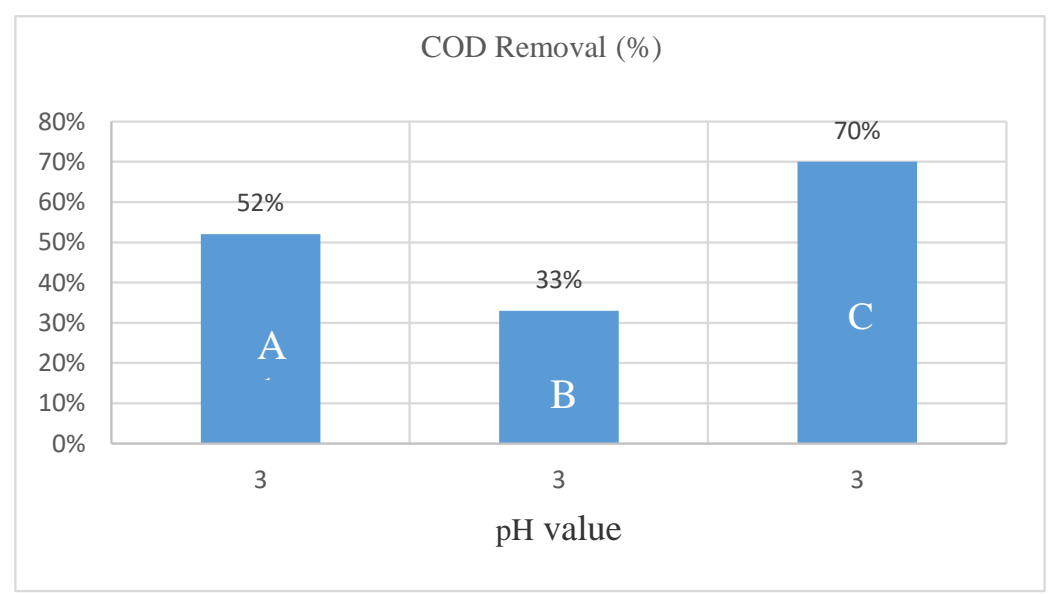

Figure 6. COD removal (\%) for three samples at $\mathrm{pH}=3$.

According to results of COD removal, Sample A and C recommended for further tests.

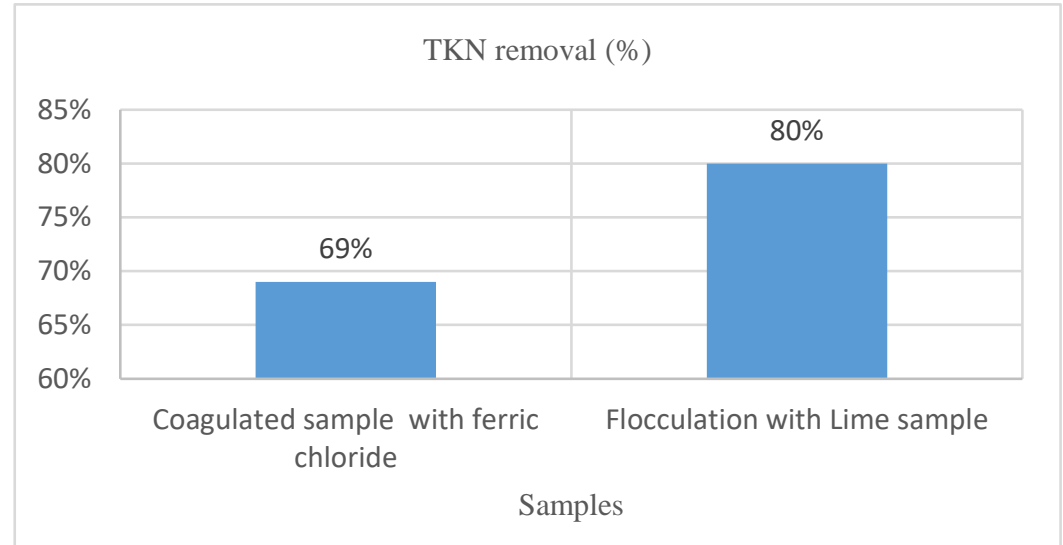

Figure 7. TKN removal (\%) for samples after fenton process. 


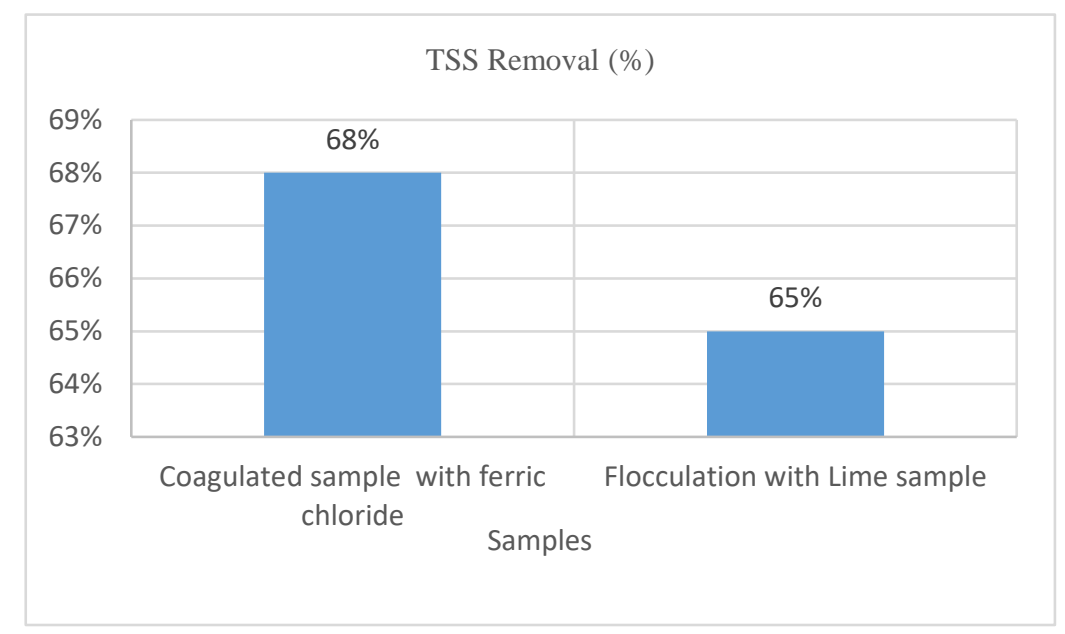

Figure 8. TSS removal (\%) for samples after Fenton process.

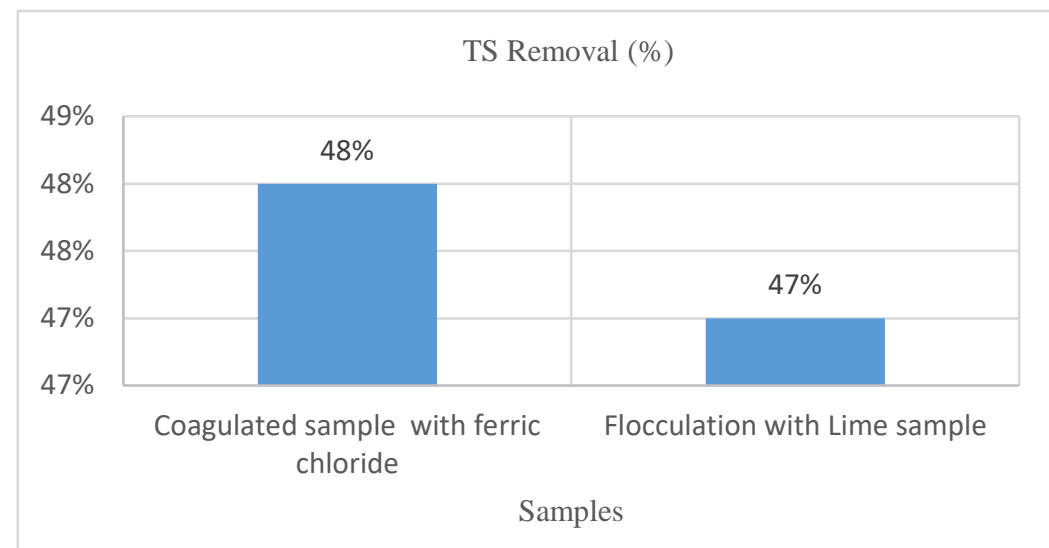

Figure 9. TS removal (\%) for samples after partially treatment.

\subsection{Effect of $\mathrm{H}_{2} \mathrm{O}_{2}$ and Catalyst Dosage on Treatment Efficacy}

In Fenton reaction process $\mathrm{H}_{2} \mathrm{O}_{2}$ is the main source of hydroxyl radical $\bullet \mathrm{OH}$ which produced under catalyst, and has a key role in reducing the organic load of wastewater. The optimal dosage of hydrogen peroxide was determined experimentally and by calculations.

Insufficient dosage or little of hydrogen peroxide $\mathrm{H}_{2} \mathrm{O}_{2}$ led to decrease in COD removal of the organic load regarding to insufficiency hydroxyl radical $\bullet \mathrm{OH}$. In contrast an increasing in dosage of $\mathrm{H}_{2} \mathrm{O}_{2}$ specially in treating wastewater with high COD value to increase the efficacy of COD removal, the excessive dosage of $\mathrm{H}_{2} \mathrm{O}_{2}$ will affect the microorganisms which used in removing contaminant, also an excessive in the concentration of $\mathrm{H}_{2} \mathrm{O}_{2}$ will result in self-disintegration into $\mathrm{H}_{2} \mathrm{O}$ and $\mathrm{O}_{2}$ [16]. Data obtained in this study are in 
compliance to what Shewa and Dagnew [17] reported. They underlined the role of AOP with coagulation and flocculation as a cost-competitive option for the pretreatment of industrial wastewaters. Advanced oxidation process is not a new technology, Peres et al. [18] listed other advanced technologies including electrochemical [19], and membrane-based processes, where AOP is increasingly applied, a competitive option for industrial wastewater treatment.

Table 2 shows the summary of removal rates (as percentages) for the min physical and chemical parameters for the three different treatment trials. Trials were made in triplicats to determine the optimal dose for $\mathrm{H}_{2} \mathrm{O}_{2}$ reaching an optimal $\mathrm{H}_{2} \mathrm{O}_{2} / \mathrm{COD}$ ratio (w/w) of 2:1.

Table 2. Removal rates of physical and chemical parameters.

\begin{tabular}{|l|l|l|l|l|l|}
\hline \multirow{2}{*}{ Sample with pretreatment options } & \multicolumn{5}{|c|}{ Removal Rates (\%) } \\
\cline { 2 - 6 } & COD & BOD & TKN & TSS & TS \\
\hline Sample with ferric chloride $\mathrm{FeCl}_{3} .6 \mathrm{H}_{2} \mathrm{O}$ & $82 \%$ & $80 \%$ & $69 \%$ & $92 \%$ & $63 \%$ \\
\hline Sample with sedimentation (without coagulant) & $33 \%$ & $29 \%$ & - & $21 \%$ & $15 \%$ \\
\hline Sample with flocculation using lime $\mathrm{Ca}(\mathrm{OH})_{2}$ & $88 \%$ & $86 \%$ & $80 \%$ & $91 \%$ & $62 \%$ \\
\hline
\end{tabular}

For $\mathrm{FeSO}_{4}$ dosage, increased quantity of catalyst will affect economy of scale for wastewater treatment, and low dosage impact the reaction due to insuffiant hydroxyl radical $(\bullet \mathrm{OH})$ production. The optimal $\mathrm{FeSO}_{4}$ dose tested has resulted in an optimal $\mathrm{H}_{2} \mathrm{O}_{2} / \mathrm{Fe}^{+2}$ of 10:1 ratio.

\section{Conclusion}

The paper addressed characterization and efficacy of AOP technology for mixed industrial effluents treatment to meet municipality by-law requirements for sewer connection. Based on the results analysis of this study, the following conclusions are elucidated:

- A pre-treatment stage before Fenton process is necessary to reduce the pollution loads as per local national requirements for organic rich industrial polluters.

- Lime addition coupled with Fenton reaction enhanced the COD removal rates.

- Application of AOP could help reduced illicit industrial discharges and enable agrofood industries connect to public sewerage networks, thus complying with Nablus CR 16/13 sewer connection by-law. 
- Scaling up the Fenton process from bench scale into pilot systems warrants further studies at small and large-scale agro-food industries.

The coagulation/flocculation was effective for the pre-treatment of agro-industrial wastewater, mainly for lowering the COD and TSS to levels, where further post-treatment stages including AOPs and/other biological processes are applied.

\section{Acknowledgment}

The Palestinian Dutch Program PADUCO2 on Water provided funding for this study.

Conflicts of Interest: The authors declare no conflict of interest.

\section{References}

1. Environmental Quality Authority (EQA). Water Pollution and its Impact on Human Health. Technical Report, Environmental Quality Authority. Ramallah, Palestine, 2015.

2. Ng, W.J. Industrial Wastewater Treatment. London: Imperial College Press, 2006.

3. Kolhe, A.S.; Ingale, S.R.; Bhole, R.V. Effluent of dairy technology. Shodh Samiksha Aur Mulyankan (Int. Res.J.), 2009, 2(5), 459-461.

4. GTZ. Anaerobic Treatment of Slaughterhouse Waste and Wastewater. Study and Report. https://energypedia.info/wiki/Anaerobic_Treatment_of_Slaughterhouse_Waste _and_Wastewater. (Accessed on 28 October 2020).

5. Ministry of Local Government. Municipal By-law on Households and Facilities: Connection System to Public Sewerage, Ramallah, Palestine, 2013.

6. Khan, M.N.; Mohammad, F. Eutrophication: challenges and solutions. In: A.A. Ansari, S.S. Gill (eds.). Eutrophication: Causes, Consequences and Control, 2014, 1-15.

7. APHA. Standard Methods for Examination of Water and Wastewater. $21^{\text {st }}$ Ed. American Public Health Association, Washington, D.C., USA, 2005.

8. Hossaini, H.; Fatehizadeh, A.; Yousefi, N.; Reshadat, S.; Gilan, N.R.; Ghasemi, S.; Ahmadian, M. Application of enhanced softening process in slaughterhouse. Indian J. Chem. Technol., 2013, 20(3), 217-221.

9. Dennett, K.E.; Amirtharajah, A.; Moran, T.F.; Gould, J.P. Coagulation: its effect on organic matter. J. Am. Water Work. Assoc. 1996, 88(4), 129-142. 
10. Leentvaar, J.; Rebhun, M. Effect of magnesium and calcium precipitation on coagulationflocculation with lime. Water Res. 1982, 16(5), 655-662.

11. Mo, W.T.; Chen, T.; Tang, Y.Y. Optimization of lime softening-flocculation treatment process of groundwater by orthogonal experiment. Chem. Bioeng. 2013, 6(27).

12. Yoo, H. C.; Cho, S.H.; Ko, S.O. (2001). Modification of coagulation and Fenton oxidation processes for cost-effective leachate treatment. J. Environ. Sci. Health, 2001, 36(1), 39-48.

13. Dulova, N.; Trapido, M. Application of Fenton's reaction for food-processing wastewater treatment. J. Adv. Oxid. Technol., 2011, 14(1), 9-16.

14. Fenton H.J.H. Oxidation of tartaric acid in presence of iron. J. Chem. Soc., Trans. 1894, 65, 899-910.

15. Katsumata, H.; Kawabe, S.; Kaneco, S.; Suzuki, T.; Ohta, K. Degradation of bisphenol an in water by the photo-Fenton reaction. J. Photochem. Photobiol. A, 2004, 162(2-3), 297-305.

16. Andreozzi, R.; Caprio, V.; Insola, A.; Marotta, R. Advanced oxidation processes (AOP) for water purification and recovery. Catal. Today, 1999, 53(1), 51-59.

17. Amor, C.; Marchão, L.; Lucas M.S.; Peres, J.A. Application of advanced oxidation processes for the treatment of recalcitrant agro-industrial wastewater: a review. Water 2019, 11, 205.

18. Shewa, W.A.; Dagnew, M. Revisiting chemically enhanced primary treatment of wastewater: A review. Sustainability 2020, 12, 5928.

19. Meiramkulova, K.; Jakupova, Z.; Orynbekov, D.; Tashenov, E.; Kydyrbekova, A.; Mkilima, T.; Inglezakis, V.J. Evaluation of electrochemical methods for poultry slaughterhouse wastewater treatment. Sustainability 2020, 12, 5110. 